\title{
Sugarcane Farmer Partnership Pattern with PTPN XIV Takalar Sugar Factory (Case Study of Partner Farmers of PTPN XIV Takalar Sugar Factory)
}

\author{
Puspitasari Dewi
}

Department of Agribusiness, Agricultural Faculty, University Muhammadiyah Makassar, Indonesia

\section{Article Info}

Volume 8, Issue 5

Page Number : 29-38

\section{Publication Issue}

September-October-2021

\section{Article History}

Accepted : 01 Sep 2021

Published : 08 Sep 2021

\section{ABSTRACT}

This study aims to analyze the pattern of sugarcane agribusiness partnerships, analyze the partnership contribution of the Takalar Sugar Factory and sugarcane farmers, and measure the level of farmer satisfaction with the partnership performance. This research was conducted from January to May 2021 in PG. Takalar and the northern Polongbangkeng District, Takalar Regency. The research methods used in this research are in-depth interviews and questionnaires. Determination of the sample used a simple random sampling method. This study also uses two key informants from PG Takalar, namely the head of the plant and also the garden cinder to find out how the partnership pattern exists between PTPN XIV Takalar Sugar Factory and partner farmers. The data analysis used a descriptive qualitative analysis and quantitative analysis. The results showed that the pattern of sugarcane agribusiness partnerships between PG. Takalar with sugarcane farmers is a sub-contract pattern. The partnership's contribution to the economic aspect is PG. Takalar provides market guarantees, capital assistance, and sharing profit-sharing. The technical aspect is PG. Takalar provides guidance and sugarcane farmers provide raw materials. The social aspect is that both parties try to cooperate according to the agreement. The environmental aspect is that both parties limit the use of chemicals. The obstacle in the collaborative activities between PTPN XIV Takalar Sugar Factory and farmers is the DO (Delivery Order) system or the provision of production results which can be in the form of money or milled products. PG partner farmers. Takalar is satisfied with the implementation of the partnership at PG. Takalar.The partnership aspect that contributes greatly to farmer satisfaction is the coaching activity of PG extension.

Keywords : Partnership, Satisfaction Level, sugarcane farmers, PG. Takalar

\section{INTRODUCTION}

Sugarcane is a product of the plantation sub-sector which is used as a raw material for the sugar industry and has a strategic role in the economy in Indonesia. Data from the Central Statistics Agency in 2020 figures in Table 1 shows that the total area of sugarcane plantations in Indonesia is 456,760 hectares, with an 
average plantation area of 202,440 hectares and smallholder plantations covering 254,320 hectares. From this total area, Indonesia produces an average total production of 2,423,520 tons of sugar cane with an average production of $1,104,940$ tons of sugar cane and an average production of 1,318,580 for smallholders. Sugarcane has a very important role as the main raw material in the sugar industry in Indonesia. Sugar is also an important commodity because it is a source of livelihood for sugarcane farmers. As an agricultural commodity, sugar has been designated as one of the special commodities. This is stipulated in the WTO (World Trade Organization) negotiation forum [6].

According to Racbhini [7], the potential for the development of plantation commodities in Indonesia is very large, but in its development, there are several problems including development strategies and institutions. The problems faced by sugarcane farmers are the lack of capital for farming, the limitations of farmers in terms of processing their land products, and difficulties in marketing their farming products, so sugarcane farmers cooperate with the sugar industry which always requires sugar cane raw materials.

The partnership between sugarcane farmers and sugar mills is an alternative to improve the efficiency of the sugarcane agribusiness value chain. For sugarcane farmers, partnerships can reduce market risk because they provide certainty about the quantity of sugarcane that can be sold and the price received [1]. This certainty makes it easier for farmers to predict the income they will receive and make the right farming decisions. Meanwhile, for sugar factories, partnerships reduce production risk and labor risk [10]. Through partnerships, sugar factories can regulate the quantity and quality of supply of raw materials. In addition, by partnering, sugar factories can reduce the costs and risks of farming labor compared to when they operate their plantations. Another risk is the risk of a labor strike carried out by the union [5].

PTPN XIV Takalar Sugar Factory (PG) is one of the sugar factories in South Sulawesi that has established partnerships with farmers. PG Takalar as a sugar production industry cannot meet the needs of its raw materials. These constraints are caused because PG Takalar does not have its sugarcane planting area or does not have land use rights to meet the needs of raw materials for sugar production, so PG Takalar gets raw materials from surrounding sugarcane farmers through a cooperative partnership. Partnering with PG Takalar is the main choice for sugar cane farmers in Takalar Regency. This is because sugarcane farmers are not able to process their farming products, in partnership with PG. Takalar, sugarcane farmers get a definite market guarantee so that sugarcane farmers have no difficulty in marketing their agricultural products, sugarcane farmers easily get production facilities and production costs from PG. Takalar so that sugarcane farmers can increase their farming productivity.

The partnership between PTPN XIV PG. Takalar with sugarcane farmers has been carried out since the establishment of PG. Takalar in 1982. The partnership between PG. Takalar and sugarcane farmers are expected to create a balance of roles and benefits for each other, to achieve the goal of a mutually beneficial partnership. This study aims (1) to analyze the pattern of partnerships (partnership patterns, rights, and obligations, contributions, constraints faced) sugarcane agribusiness in North Polongbangkeng District and (2) to measure the level of farmer satisfaction with the pattern and implementation of partnerships with PTPN XIV Takalar Sugar Factory.

\section{RESEARCH METHOD}

This research was carried out at PTPN XIV Takalar Sugar Factory and Sugar Cane Farmers in North Polongbangkeng District, Takalar Regency from January to May 2021. Takalar PG is one of the PGs that runs partnerships with sugarcane farmers intensively.

The population in this study were sugarcane farmers who established a partnership with PTPN XIV Takalar Sugar Factory in Pa'rapunganta Village, Pollongbangkeng Utara District, Takalar Regency with 250 farmers partnering. The population in this study, so the sampling technique used is the simple random sampling method. Simple random sampling is a sampling method that is carried out randomly because the population is considered homogeneous so 
that the sample is considered to be representative of the population [12]. Sumanto [13] revealed that the smallest acceptable sample size for descriptive research is at least $10 \%$ of the population, so the number of samples taken is 25 people. This study also uses two key informants from PG Takalar, namely the head of the plant and also the garden cinder to find out how the partnership pattern exists between PTPN XIV Takalar Sugar Factory and partner farmers.

Data analysis in this study used qualitative descriptive methods and quantitative methods. Qualitative descriptive method to describe the pattern of the partnership between sugarcane farmers and PTPN XIV Takalar sugar factory based on information from respondents and key informants, conclusions are drawn. The quantitative method is used to measure the level of farmer satisfaction by using a Likert scale. According to Nazir [9] that the Likert Scale is a psychometric scale used in evaluating a program or policy of a plan. The Likert scale is also a technique that can be used to measure agreement and disagreement or satisfaction and dissatisfaction of a person with a program plan, program implementation ,or the level of success of a program. In addition, the Likert scale is also used to measure the perception, attitude, or opinion of a person or group regarding an event or social phenomenon.

Tabel. 1. Satisfaction Indicators For each aspect of the partnership

\begin{tabular}{|c|l|l|}
\hline $\begin{array}{c}\text { Partnership } \\
\text { Aspect }\end{array}$ & No & \multicolumn{1}{|c|}{ Indicator } \\
\hline \multirow{2}{*}{$\begin{array}{c}\text { Admission } \\
\text { Procedure }\end{array}$} & 1 & $\begin{array}{l}\text { Service Application to } \\
\text { become a partner farmer }\end{array}$ \\
\cline { 2 - 3 } & 2 & $\begin{array}{l}\text { The process of measuring } \\
\text { land area by PG Takalar is } \\
\text { one of the requirements to } \\
\text { become a partner farmer }\end{array}$ \\
\hline $\begin{array}{c}\text { Farmer } \\
\text { Coaching } \\
\text { Activities }\end{array}$ & 1 & $\begin{array}{l}\text { Relationship between } \\
\text { farmer and facilitator }\end{array}$ \\
\cline { 2 - 3 } & 2 & How the Companion \\
\hline
\end{tabular}

\begin{tabular}{|c|c|c|}
\hline & & communicates with farmers \\
\hline & 3 & $\begin{array}{l}\text { Companion's visit } \\
\text { farmer's land }\end{array}$ \\
\hline & 4 & $\begin{array}{l}\text { the Companion that is easy } \\
\text { to find or easy to contact }\end{array}$ \\
\hline & 5 & $\begin{array}{l}\text { Information about } \\
\text { cultivation provided by the } \\
\text { companion }\end{array}$ \\
\hline & 6 & $\begin{array}{lrr}\text { Providing } & \text { input from } \\
\text { assistants } & \text { regarding } \\
\text { cultivation } & \text { problems faced }\end{array}$ \\
\hline & 7 & $\begin{array}{l}\text { Companion's level of } \\
\text { knowledge about sugar cane } \\
\text { from start to finish }\end{array}$ \\
\hline \multirow{2}{*}{$\begin{array}{l}\text { Clear SOPs } \\
\text { related to } \\
\text { production } \\
\text { results by } \\
\text { following per } \\
\text { under factory } \\
\text { needs }\end{array}$} & 1 & $\begin{array}{l}\text { Ready-to-harvest sugarcane } \\
\text { standards set by PG }\end{array}$ \\
\hline & 2 & Sugarcane standard ready \\
\hline \multirow{4}{*}{$\begin{array}{l}\text { Sugarcane } \\
\text { Milling } \\
\text { Production } \\
\text { Facilities and } \\
\text { Production } \\
\text { Sharing }\end{array}$} & 1 & $\begin{array}{l}\text { Sugarcane Milling } \\
\text { Production Facilities }\end{array}$ \\
\hline & 2 & Sugarcane Milling Results \\
\hline & 3 & $\begin{array}{l}\text { Predefined profit-sharing } \\
\text { system }\end{array}$ \\
\hline & 4 & $\begin{array}{l}\text { Time of giving information } \\
\text { on milled yields related to } \\
\text { yield }\end{array}$ \\
\hline \multirow{4}{*}{$\begin{array}{l}\text { Takalar Sugar } \\
\text { Factory's } \\
\text { Response to } \\
\text { Farmers' } \\
\text { Complaints }\end{array}$} & 1 & $\begin{array}{l}\text { PG Takalar's response if } \\
\text { farmers make complaints }\end{array}$ \\
\hline & 2 & $\begin{array}{l}\text { PG Takalar can accept input } \\
\text { or criticism from farmers as } \\
\text { plasma parties }\end{array}$ \\
\hline & 3 & $\begin{array}{l}\text { PG Takalar's response to } \\
\text { farmers' complaints }\end{array}$ \\
\hline & 4 & $\begin{array}{lr}\text { Solutions } & \text { provided by PG } \\
\text { Takalar } & \text { regarding } \\
\text { complaints } & \text { submitted by } \\
\text { farmers } & \end{array}$ \\
\hline
\end{tabular}

Based on the questionnaire and with a Likert scale to determine the level of satisfaction of partner farmer respondents consisting of choices (optional) and the scores are: 
Tabel 2. Likert scale

\begin{tabular}{|l|c|}
\hline \multicolumn{1}{|c|}{ Answer Options } & Scor \\
\hline Very satisfied & 5 \\
\hline Satisfied & 4 \\
\hline Enough & 3 \\
\hline Not satisfied & 2 \\
\hline Very Dissatisfied & 1 \\
\hline
\end{tabular}

Where then determine the average level of satisfaction according to the Likert method in Nazir [9] by using the formula.

\section{Average satisfaction $=\underline{\text { Total score of questionnaire }}$ answers}

Total number of questionnaires

And to determine the average satisfaction using Norton's theory:

Tabel 3. Average satisfaction

\begin{tabular}{|c|l|}
\hline Range nilai & \multicolumn{1}{|c|}{ Keterangan } \\
\hline $1-1.79$ & Very dissatisfied \\
\hline $1.8-2.59$ & Not satisfied \\
\hline $2.6-3.39$ & Enough \\
\hline $3.4-4.19$ & Satisfied \\
\hline $4.2-5$ & Very satisfied \\
\hline
\end{tabular}

From the results of the calculation of the formula above, we can obtain the level of satisfaction of partner farmers with the partnership pattern carried out with PTPN XIV PG Takalar.

\section{RESULT AND ANALYSIS}

\subsection{Respondent Characteristics}

Respondents in this study were partner sugarcane farmers in North Polongbangkeng District, Takalar Regency. The number of respondents in this study was 25 people and 2 (two) key informants from the PG. Takalar. Characteristics of respondents consist of age, education level , and farming experience in detail can be seen in Table 4 .

Table 4. Characteristics of Respondents in North Polongbangkeng District, Takalar Regency in 2021.

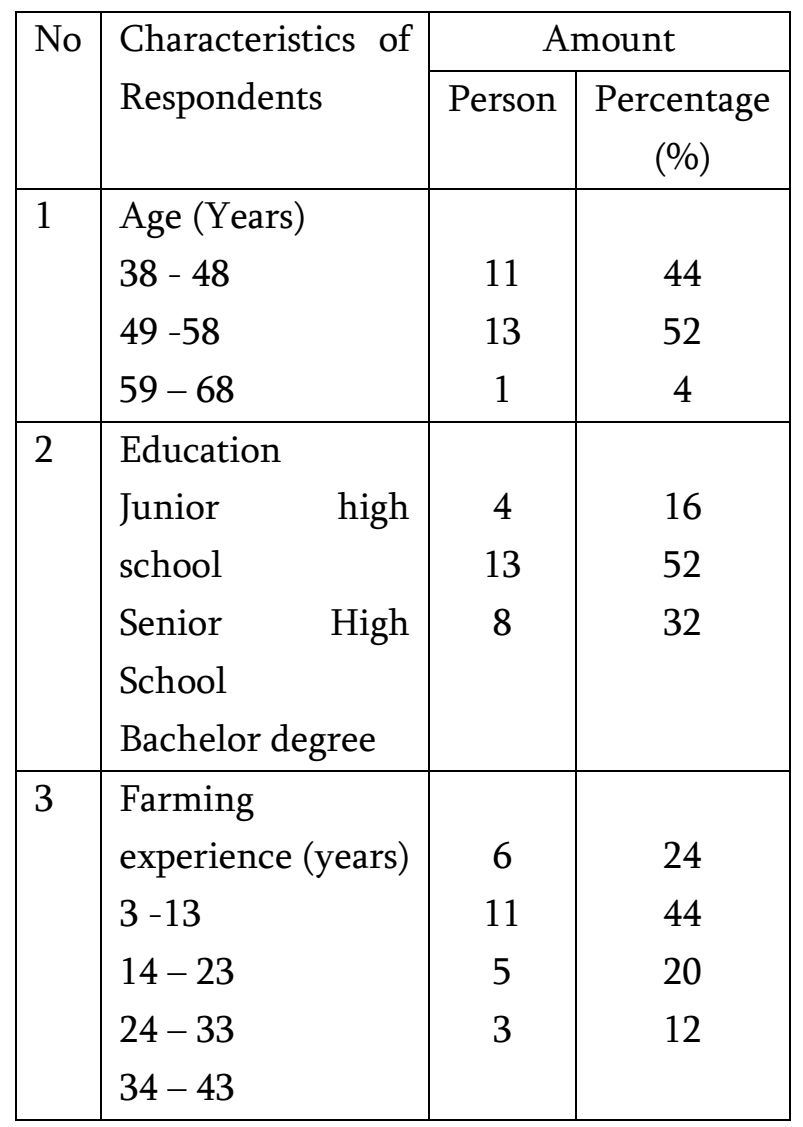

Source: Processed from research primary data, 2021 Based on Table 1. It is known that the majority of respondents are in the age range of $49-58$ as many as 52 people (52\%). The average age of sugarcane farmer respondents is 53 years. This shows that most of the respondents belong to the productive age, namely 49 58 years, so that respondents have the potential to manage and develop sugarcane farming, and are able to increase their work productivity.

The education level of the respondents is quite diverse with the highest education level being SMA and the lowest education level being SMP. Respondents who have a junior high school level are 4 people (16\%), a high school education level is 13 people (52\%), an undergraduate education level (S1) is 8 people (32\%). This shows that the majority of 
respondents in Polongbangkeng Utara District, Takalar Regency have taken a fairly.

good level of education, namely 12-year compulsory education in accordance with the regulation of the Minister of Education and Culture of the Republic of Indonesia No.19 of 2016. The level of education owned by farmers affects the decision to take farming decisions to be carried out as well as how to analyze market opportunities and profits to be received [3].

The respondent's experience in sugarcane farming in Polongbangkeng Utara District, Takalar Regency is the most, namely $14-23$ years with 11 people (44\%) . The respondents' average farming experience was 18.9 years. This proves that respondents in North Polongbangkeng District are experienced enough in sugarcane farming, so that farmers can manage their farming.

\subsection{Key Informant Characteristics}

The key informants used in this study were 2 people from PG. Takalar who is related and knows the information for this research. Key informants occupy the positions of head of plant and garden cinder, head of plant is 39 years old with a bachelor's education and garden cinder is 40 years old with a bachelor's last education.

\subsection{Partnership Pattern}

\section{A. Partnership Mechanism}

Partnership is a business strategy carried out by 2 (two) or more parties, within a certain period time, to achieve mutual benefits with the principle of mutual need and mutual support [4]. Before collaborating with the Takalar Sugar Factory, the farmers first applied to cooperate with PTPN XIV Takalar Sugar Factory to collect data on the farmers. After that, the next stage is PG Takalar measuring the farmers' land area to be planted with sugar cane, when the farmers have gone through the stages above and approved by the $P G$ then the farmers join to become members of the farmer group, when the farmer has become a member of the farmer group, then the farmer will immediately become a partner of PTPN XIV PG Takalar.

Based on the results of interviews from key informants and respondents that the PG partnership pattern. Takalar with sugarcane farmers in North Polongbangkeng District, Takalar Regency using a sub-contract pattern. PG Takalar acts as a partner company and sugarcane farmers act as a partner group. PG. Takalar as a partner company plays a role in assisting sugarcane farmers. The assistance provided by PG. Takalar to sugarcane farmers is in the form of capital assistance/credit used as production costs, guaranteed market guarantees, technical development of cultivation, and assistance with technology packages and production infrastructure. Sugarcane farmers are obliged to submit all their harvests to PG. Takalar according to the agreement and schedule that has been given. PG. takalar provides convenience to sugarcane farmers so that they can easily get the facilities needed by sugarcane farmers in carrying out their farming which aims to ensure the activities of sugarcane farmers run smoothly and are continuous.

In conducting partnership activities with farmers, there is a mechanism for partnership activities between PG Takalar and farmers as follows:

\section{Become a partner farmer of PG Takalar}

Before collaborating with the Takalar Sugar Factory, the farmers first applied to cooperate with PTPN XIV Takalar Sugar Factory in to collect data on the farmers. After that, the next stage is PG Takalar measuring the farmers' land area to be planted with sugar cane, when the farmers have gone through the stages above and approved by the PG then the farmers join to become members of the farmer group, when the farmer has become a member of the farmer group, 
then the farmer will immediately become a partner of PTPN XIV PG Takalar.

2. Farmers carry out cultivation activities through guidance from PG Takalar

After becoming a partner of the Takalar Sugar Factory, the farmer carries out his duties or obligations as a partner of the Takalar Sugar Factory. Farmers then carry out sugarcane cultivation activities on land that have been registered, of course, these sugarcane cultivation activities are also under the guidance of PG Takalar. PTPN XIV Takalar Sugar Factory guides farmers from the beginning of planting to postharvest.Proses.

3. Milling and selling of milled products

After the farmers carry out the cultivation process to the stage of loading and unloading where at this stage the farmers have produced sugar cane which are included in the categories of Cane Worth Cutting (TLT) and Cane Worth Milling (TLG) then the farmers submit all of their sugarcane products according to the production produced to the Sugar Factory. and also with the applicable schedule that has been determined by the Sugar Factory.

B. Rights and obligations of farmer partnership and PG Takalar

$>$ Rights of PG Takalar and Partner Farmers

1. PG Takalar has the right to receive sugar cane from a second party and grind all of the farmers' sugarcane products that are registered and eligible to be milled, this shows that partner farmers are not allowed to give their sugarcane cultivation products to other parties other than PTPN XIV Takalar Sugar Factory.

2. PG Takalar has the right to refuse sugarcane that does not meet the requirements as agreed in the agreement, these conditions are regulated in the article of the agreement in the form of Cane Worth Cutting (TLT).

3. PG Takalar has the right to deduct all loans and dependents that are borne by the second party through the sale of sugar and molasses.
4. Partner farmers are entitled to technical guidance on sugarcane cultivation from PG.Takalar

5. Partner farmers get the results of weighing, milling , and processing sugar cane by following per under the applicable profit-sharing provisions.

Obligations of PG Takalar and Partner Farmers

- PG Takalar is obliged to carry out registration for farmers who want to register as partners, after farmers register then PG will measure the area of land that will be planted with sugar cane by farmers, this is also very beneficial for farmers because most farmers do not know the exact size of their land.

- PG Takalar is obliged to provide technical guidance in the field to achieve high productivity. What is meant by technical guidance is that the PG sends Cinder or the garden supervisor who directly communicates with partner farmers on the land, it is the Cinder who communicates and provides direct guidance to farmers.

- Partner farmers carry out the sugarcane cultivation process which is of course accompanied by PG Takalar to get high productivity.

- Partner farmers produce sugarcane by following and under the established standards, namely Cane Worth Cutting (TLT) and Cane Worth Milling (TLG), farmers are also required after they harvest their sugarcane cultivation which of course has met the TLT requirements to be handed over to PG Takalar and not on the other.

C. Partnership Contribution between PG. Takalar and Sugar Cane Farmers.

According to Widyantara [15] that the essence of the partnership lies in joint contributions, both in the form of labor, land, and capital for economic purposes where the management is carried out together and the sharing of profits and losses is shared. PG 
contribution. Takalar and sugarcane farmers in a partnership consisting of economic aspects, technical aspects, social aspects, and environmental aspects.

a. For the economic aspect, PG's contribution. Takalar to sugarcane farmers: (1) makes it easy for farmers to get production costs used by farmers for sugarcane farming, (2) provides a definite market guarantee with distribution according to the mutual agreement

b. For the technical aspect, the contribution of Pg. Takalar to sugarcane farmers, namely (1) PG. Takalar assists with the procurement of agricultural production facilities to sugarcane farmers, (2) provides guidance related to sugarcane cultivation to farmers to obtain quality sugarcane.

c. For the social aspect, namely (1) both parties try to cooperate by following per under what has been agreed so that the partnership between PG. Takalar and sugarcane farmers are continuity and each party benefits.

D. Partnership Constraints between PG. Takalar and Sugarcane Farmers

The obstacle in the collaborative activities between PTPN XIV Takalar Sugar Factory and farmers is the DO (Delivery Order) system or the provision of production results which can be in the form of money or milled products. The above is considered by farmers to still be an obstacle until now. Because giving DO is considered slow, even for weeks, it can cause farmers to not have the capital to reprocess their land so that they can grow sugar cane again. Farmers also really hope that this DO grant can be accelerated by a maximum of one week so that the results can be replayed by farmers. From the results of interviews with Mr. N, partner farmers, the researchers obtained information about the obstacles faced by farmers, namely:

"Until now, the only obstacle is taking farmers' production such as DO or Delivery Orders, here we do see that the DO completion rate is a bit slow because we expect that after the closing period, the maximum period of about one week because these farmers I want to use it again for activities. Here, we farmers do not understand what the point is until it takes two weeks to give it, so that it hampers the activities of the farmers because the hope is that the farmers will turn around again, the sugar will be sold and the results will continue to be used for cultivation, but that might also be because there are many farmers right? what PG needs to pay attention to, and when it's milling season, it's too much work too. So we hope that there is a special system to handle that. because that's the only problem, other than that I think it's going well." (interview with Mr. N on 27-11-2020)

\subsection{The Satisfaction Level of Partner Farmers with the Implementation of the Partnership with PTPN XIV Takalar Sugar Factory}

The results of the satisfaction level assessment using the scoring method showed that in general, the farmers were satisfied with the implementation and the partnership pattern. For farmers, the partnership activity with PG Takalar is considered quite good over time, this shows that PG is also very concerned about farmers. With the existence of a contractual bond between the Sugar Factory and partner farmers, all activities are carried out based on the existing contract or agreement, such as the rights and obligations of each party. From this research, we also see how PG Takalar has carried out its obligations well.

Table 5. Recapitulation of Farmer Satisfaction Levels with Partnership Pattern with PTPN XIV Takalar Sugar Factory

\begin{tabular}{|c|l|c|l|}
\hline No. & $\begin{array}{l}\text { Question } \\
\text { description }\end{array}$ & $\begin{array}{l}\text { Average } \\
\text { score }\end{array}$ & Descriptive \\
\hline 1. & $\begin{array}{l}\text { Admission } \\
\text { procedure }\end{array}$ & 4,06 & Satisfied \\
\hline 2. & $\begin{array}{l}\text { Farmer coaching } \\
\text { activities }\end{array}$ & 4,31 & $\begin{array}{l}\text { Very } \\
\text { satisfied }\end{array}$ \\
\hline
\end{tabular}




\begin{tabular}{|c|l|c|l|}
\hline 3. & $\begin{array}{l}\text { Clear S.O.P } \\
\text { regarding } \\
\text { production results } \\
\text { in accordance with } \\
\text { factory regulations }\end{array}$ & 4,16 & Satisfied \\
\hline $\mathbf{4 .}$ & $\begin{array}{l}\text { Sugarcane milling } \\
\text { production facilities } \\
\text { and profit sharing }\end{array}$ & 3,94 & Satisfied \\
\hline 5. & $\begin{array}{l}\text { Response to farmer } \\
\text { complaints }\end{array}$ & 4,49 & Very \\
\hline & Jumlah & 20,96 & satisfied \\
\hline & Rata-rata & 4,19 & Satisfied \\
\hline
\end{tabular}

Source: Primary data after processing, 2021

For the acceptance procedure, there are two stages, namely the application service to become a partner farmer, and the land area measurement procedure carried out by PG Takalar as one of the requirements to become a partner farmer. Through interviews conducted with partner farmer respondents, it was acknowledged that the service or procedure for accepting partner farmers at PG Takalar had been carried out well and of course the farmers were satisfied with it. Not only that, this service or acceptance procedure also turns out to be beneficial for farmers who do not know the size of their land or do not have a picture of their land so that PG Takalar measures the area of their land, provides pictures related to their land, and even takes a production assessment on the farmer's land. The results of Mega's research [8] show that based on a survey conducted to the respondent's partner sugarcane farmers, the partnership acceptance procedure carried out at PG Pakis Baru is not complicated and easy and the service is very friendly. We can also see that with an uncomplicated acceptance procedure, as well as very friendly services, it is easier for sugarcane farmers to become partner farmers and this is also a supporting factor for sugarcane farmers to want to register as partner farmers. This also does not mean that the company does not stipulate general conditions, but the company provides the main requirements that are needed and do not burden farmers as in the case of PG Takalar, sugarcane farmers must have unused land and be ready to be used as cultivation land. sugarcane. With the above procedure, it is proven that the farmers are satisfied with the implementation of the acceptance procedure.

One of the important aspects of the partnership that exists between PTPN XIV Takalar Sugar Factory and partner farmers is farmer development activities. In the partnership that exists, farmers as plasma parties are obliged to cultivate and produce sugar cane as raw material for sugar for the core party, namely PTPN XIV PG Takalar, of course, in sugarcane cultivation activities, farmers need guidance from PG Takalar so that farmers produce sugar cane in large quantities but also of good quality by following per under conditions that have been determined by the PG Takalar. The results of the above discussion, it is also in line with the results of research by Rhondi [11] to increase the quantity and quality of sugar raw materials, namely sugar cane, which is accepted by PG, namely by intensifying technical guidance at the farming stage, because intensive technical guidance has a positive impact on production. farming. As explained at the beginning of the discussion and also from the results of this study, it shows that technical guidance or farmer development activities are one of the important aspects in partnership activities, it is proven that it can have a positive impact, besides that farmer guidance activities are also considered very important because of In this coaching, farmers get information and knowledge about good sugarcane cultivation. Furthermore, farmer development activities are also one of the activities in which PG Takalar through its cylinder can monitor farmers' cultivation activities so that the sugarcane produced is by following per under the conditions set by PG Takalar to prevent farmers' sugarcane from being rejected for grinding which can make farmers make a loss. So with the activity of fostering farmers, farmers 
can produce more sugar cane and of course with good quality and by following per under the conditions determined by the company, namely PG Takalar.

Farmers are quite satisfied with the S.O.P which is related to production results by following per under the needs of the factory, this is in line with research conducted by Mega [8] with the title Analysis of partner sugarcane farmers' satisfaction with the partnership with PG Pakis Baru. In this study, the partner farmers of PG Pakis Baru have also been satisfied with the existence of S.O.P which is related to the partner's sugarcane production by following per under the agreed requirements of the factory. This also shows that in a partnership it is important to have S.O.P so that everything can run as it should, including the production results must have standards to achieve good production results, but the standards set also do not burden farmers.

Production facilities or production inputs are certainly important for farmers, in line with Rondhi's research [11] where farmers hope that production inputs and production facilities are improved to support better production. This shows how production suggestions also affect production. At PG Takalar itself, sugarcane milling production facilities are very supportive of how the final results will be obtained by farmers. That is, if the sugarcane milling facility is experiencing problems or obstacles, it will be a little detrimental to the farmers because the farmers' sugarcane that is ready to be milled with this problem will be stored and cause the yield contained in the sugar cane to decrease and will affect the final result. Also related to profit sharing, it is very important to determine the right profit sharing system in sugarcane farming partnership activities, in contrast to the ARI system which is more accepted in PG Takalar, the determination of the profit sharing system using the expanse system in PG Wonolangan is not accepted by farmers. The results showed that the majority of farmers only felt satisfied with this system, because this system took the yield value based on the average yield value of all processed sugarcane.
Farmers with good sugarcane quality will get a yield below the expected yield because the farmer's sugarcane is processed together with sugar cane that has lower quality [11]. This shows that it is important for the company to determine the right system to determine the profit sharing of sugarcane milling so as not to harm farmers.

Farmer satisfaction regarding PG Takalar's response to farmers' complaints shows that farmers are very satisfied with PG Takalar who have been very responsive to any complaints or problems raised by farmers. In line with Mega's research [8] how PG's response is also very important in partnership activities because With the response from PG Pakis Baru to the complaints of partner sugarcane farmers, it will be able to minimize losses due to the failure of partner sugarcane farmers. This shows how important it is to respond to farmer complaints, by responding to farmers' complaints, not only the benefits of the farmers but for both parties because the failure of farmers in cultivation activities can also affect the company which of course the incoming sugarcane supply will also decrease. Furthermore, responding to farmers' complaints will make farmers feel that they are also an important aspect of the partnership activities being carried out, so that partnership activities with farmers can last a long time.

\section{IV.CONCLUSION}

Based on the results of research and discussion on the pattern of sugarcane agribusiness partnerships in North Polongbangkeng District, the partnership pattern applied is a sub-contract partnership between PG. Takalar and sugarcane farmers. The contribution of PG Takalar and farmers in the partnership consists of economic aspects, technical aspects, social aspects and environmental aspects.

Based on the results of research and discussion on the pattern of sugarcane agribusiness partnerships in North Polongbangkeng District, the partnership 
pattern applied is a sub-contract partnership between PG. Takalar and sugarcane farmers. The contribution of PG Takalar and farmers in the partnership consists of economic aspects, technical aspects, social aspects and environmental aspects.

\section{REFERENCES}

[1]. Bellemare, M.F. 2012. As You Sow, So Shall You Reap: The Welfare Impacts of Contract Farming World Development .Online40 (7), 1418-1434, Available From doi:10. 1016/j. Worlddev. 2011.12.008.

[2]. BPS. 2020. Statistik Indonesia dalam angka 2020. Badan Pusat Statistik Jakarta.

[3]. Cahyarubin, A. Analisis Pendapatan UsahtaniTebu Petani Mitra dan Non Mitra PG Rejoagung Baru, Kabupaten Madiun. Skripsi. Program Pasca Sarjana Institut Pertanian Bogor, Bogor.

[4]. Hafsah, M.J. 2000. Kemitraan Usaha. Sinar Harapan, Jakarta.

[5]. Holly Wang, H. Zhang, Y.\& Wu,L. (2011). Is contract farming a risk management instrument for Chinese farmers in shandong. China Agricultural Economis Review. Online\} 3 (4) 489 -504. Available. From: doi: 10.1108/17561371111192347.

[6]. Utami, A., Dinar dan S.Kosasih. 2016. Pengaruh Pola Kemitraan Terhadap Pendapatan Petani Tebu (Suatu kasus di PT. PG Rajawali II, Unit PG Rajawali II, Unit PG jatitujuh, Majalengka, Jawa Barat). J. Ilmu Pertanian dan Peternakan Universitas Majalengka. 4(1): 1-8.

[7]. Rachbini, D. J. 1997. Potensi dan Strategi Pengembangan Kelembagaan Agribisnis. Prosiding Insdutrialisasi, Rekayasa Sosial dan Peranan Pemerintah dalam Pembangunan Pertanian. Pusat Penelitian Kementerian Pertanaian, Jakarta.

[8]. Mega, P.E. 2013. Analisis Kepuasan Petani Tebu Mitra Terhadap Kemitraan dengan PT Pakir
Baru. Skripsi. Fakultas Ekonomi dan Bisnis, Institut Pertanian Bogor.

[9]. Nazir, Moh. 2014. Metode Penelitian. Jakarta : Ghalia Indonesia.

[10]. Oya, C. (2012). Contrac Farming in SubSaharan Africa: A Survey of Approaches. Debates and Issues, Journal of Agrarian Changes. Online2 (1), 1-33. Available. From: doi: $\quad$ https;//doi.org/10.1111/j.14710366.2011.00337x.

[11]. Rondi, Muhammad. Kristanti, Sumekar, dan Mardiningsih, 2019. Tingkat Kepuasan Petani Tembakau Terhadap Program Kemitraan Usaha dengan PT Sadhana Arif Nusa di Kecamatan Ngimbang Kabupaten Lamongan. Jurnal Sungkai Vol.6 No.2 Thn 2019. Semarang, Indonesia.

[12]. Sugiyono. 2016. Metode Penelitian Kuantitatif dan kualitatif. Alfabeta, Bandung

[13]. Sumanto, 1990. Metodologi Penelitian Social dan Pendidikan. Penerbit ANDI, Yogyakarta.

[14]. Widyantara, W. 2018. Ilmu Manajemen Usahatani. Uadayana University Press, Bali.

\section{Cite this article as :}

Puspitasari Dewi , "Sugarcane Farmer Partnership Pattern with PTPN XIV Takalar Sugar Factory (Case Study of Partner Farmers of PTPN XIV Takalar Sugar Factory)", International Journal of Scientific Research in Science and Technology (IJSRST), Online ISSN : 2395-602X, Print ISSN : 2395-6011, Volume 8 Issue 4, pp. 29-38, September-October 2021. Available at doi : https://doi.org/10.32628/IJSRST2184102

Journal URL : https://ijsrst.com/IJSRST2184102 